УДК 81'23

ОБРАЗ УНИВЕРСИТЕТА, СТОЯЩИЙ ЗА СЛОВАМИ ОБРАЗОВАНИЕ, ВУЗ, УНИВЕРСИТЕТ В СОЗНАНИИ СОВРЕМЕННЫХ СТУДЕНТОВ

\author{
Е.А. Таныгина, Т.С. Никитенкова
}

Юго-Западный государственный университет, Курск

В статье приводятся результаты исследования с использованием ассоциативного эксперимента и семантического дифференциала, проведенного с целью выявления специфики образа современного университета в языковом сознании русскоязычных студентов.

Ключевые слова: университет, образ, языковое сознание, ассочиативный эксперимент, семантический дифференциал.

Высшее образование - штамп, обязанность или призвание? ВУЗ учение или мучение? Каково отношение современной молодежи к образованию? В настоящее время получение высшего образования является приоритетной задачей практически для каждого человека, независимо от его пола и возраста. В вузы поступают не только выпускники школ, но и специалисты, имеющие большой опыт практической деятельности: многие должности могут занимать только специалистов с высшим образованием.

В словарях мы находим такое определение: образование - это «процесс усвоения знаний, обучение, просвещение; совокупность знаний, полученных в результате систематического обучения» [13]. Это «процесс и результат усвоения систематизированных знаний, умений и навыков. В процессе образования происходит передача от поколения к поколению знания всех тех духовных богатств, которые выработало человечество, усвоение результатов общественно-исторического познания, отражённого в науках о природе, обществе, в технике и искусстве, а также овладение трудовыми навыками и умениями. Образование - необходимое условие подготовки к жизни и труду, основное средство приобщения человека к культуре и овладения ею; фундамент развития культуры» [3]. К сожалению, в повседневной жизни мы все чаще сталкиваемся с негативным отношением к этому понятию. Например, многие люди утверждают, что качество образования становится с каждым годом все хуже и хуже.

Но как на самом деле относятся будущие работники к своей деятельности, образованию и обучению? Что стоит в сознании современного носителя языка за относящимися к сфере образования словами?

Для исследования сформированного в сознании современных студентов концепта образования, а конкретно - отношения к университету и образованию в целом был проведен разведывательный эксперимент с использованием стандартных экспериментальных методик. В эксперименте приняли участие 161 студент Юго-Западного государственного университета в возрасте от 17 до 23 лет (44 девушки и 117 юношей), учащиеся факультета фундаментальной и прикладной информатики (61 человек), механикотехнологического факультета (55 человек), естественно-научного факультета 
(19 человек), факультета государственного управления и международных отношений (15 человек), факультета экономики и менеджмента (5 человек), факультета строительства и архитектуры (4 человека). Целью исследования было выявление выраженного языковыми средствами образа университета в сознании современных студентов. Было также определено отношение студентов к высшему образованию, выявлены параметры, обуславливающие выбор специальности и предметов для сдачи ЕГЭ.

При восприятии чего-либо извне в сознании человека закладывается понятие, формируется суждение о данном «предмете» и складывается образ воспринимаемого объекта, для описания которого служит язык. В психолингвистике образ - результат и идеальная форма отражения предметов и явлений материального мира в сознании человека [9]. Понятие «образ» трактуется нами с позиции психологии как мысленный, сформированный в сознании образ воспринимаемого человеком объекта окружающей среды. Это некое «знание», стоящее за словом, причем частью этого знания является культурный и чувственный опыт индивида [12]. Доступ к нему осуществляется через слово, «вбирающее» в себя многочисленные оттенки отношения к явлению действительности, закрепляющиеся в личностных смыслах.

Для выявления стоящего за относящимися к сфере образования словами образа университета в сознании студентов мы использовали предложенный в наших более ранних работах $[8,9]$ комплекс экспериментальных методик: анкетирование, свободный ассоциативный эксперимент, семантический дифференциал.

На первом этапе исследования (который проводился как контрольная процедура для «сверки» выраженного в обдуманных высказываниях и «скрытого» за словами отношения) было проведено анкетирование. Аудитории необходимо было охарактеризовать отношение к выбору своей специальности, выбору предметов для сдачи единого государственного экзамена и к образованию в целом. Были предложены следующие вопросы:

1. Высшее образование это «хорошо» или «плохо»?

2. Высшее образование - это...

3. Выбранная вами специальность - это...

4. Причина вашего выбора дополнительных предметов для сдачи ЕГЭ...

На каждый из вопросов было предложено несколько вариантов ответов (по сути, информантам были предложены задания на множественный выбор). В случае, когда предложенный ответ не подходил, можно было написать свой вариант. Результаты этого этапа исследования приводятся в табл. 1. В следующем ниже обсуждении результатов эксперимента реакции студентов будут даны курсивом (в ответах студентов сохранена оригинальная орфография и пунктуация). 
Таблица 1. Результаты анкетирования

\begin{tabular}{|c|c|c|c|c|}
\hline \begin{tabular}{l}
0 \\
0 \\
\hdashline \\
\hdashline \\
0
\end{tabular} & $\begin{array}{l}\text { Высшее } \\
\text { образование } \\
\text { это } \\
\text { «хорошо» или } \\
\text { «плохо» }\end{array}$ & $\begin{array}{l}\text { Высшее } \\
\text { образование - это }\end{array}$ & $\begin{array}{l}\text { Выбранная } \\
\text { вами } \\
\text { специальность } \\
\text { - это... }\end{array}$ & $\begin{array}{l}\text { Причина вашего } \\
\text { выбора } \\
\text { дополнительных } \\
\text { предметов для сдачи } \\
\text { ЕГЭ }\end{array}$ \\
\hline \multirow{4}{*}{ 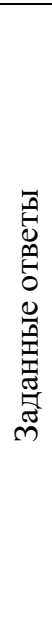 } & $\begin{array}{l}\text { Хорошо } \\
65,8 \%\end{array}$ & $\begin{array}{l}\text { Средство для } \\
\text { достижения цุели } \\
33,7 \%\end{array}$ & $\begin{array}{l}\text { Осознанный } \\
\text { выбор } \\
45,5 \%\end{array}$ & $\begin{array}{l}\text { То, что нужно для } \\
\text { поступления } \\
54 \%\end{array}$ \\
\hline & $\begin{array}{l}\text { Скорее хороио } \\
28 \%\end{array}$ & $\begin{array}{l}\text { Средство для } \\
\text { устройства на } \\
\text { работу } \\
31.6 \%\end{array}$ & $\begin{array}{l}\text { То, что нужно } \\
\text { для } \\
\text { достижения } \\
\text { цели } \\
30,6 \%\end{array}$ & $\begin{array}{l}\text { То, что наиболее } \\
\text { интересно } \\
32,3 \%\end{array}$ \\
\hline & $\begin{array}{l}\text { Плохо } \\
2,4 \%\end{array}$ & $\begin{array}{l}\text { Очередной этап в } \\
\text { жизни } \\
26,7 \%\end{array}$ & $\begin{array}{l}\text { Просто нужно } \\
\text { высшее } \\
\text { образование } \\
11,8 \%\end{array}$ & $\begin{array}{l}\text { То, что легче сдать } \\
5 \%\end{array}$ \\
\hline & $\begin{array}{l}\text { Скорее плохо } \\
0,62 \%\end{array}$ & $\begin{array}{l}\text { Модно, } \\
\text { престижно } \\
4,3 \%\end{array}$ & $\begin{array}{l}\text { Случайность } \\
10,8 \%\end{array}$ & \\
\hline 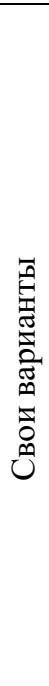 & $\begin{array}{l}\text { Зачастую } \\
\text { просто } \\
\text { бесполезно и } \\
\text { нудно } \\
\text { - } 0,62 \% \\
\text { Очень хорошо } \\
0,62 \% \\
\text { Смотря какое, } \\
\text { смотря } \\
\text { где } 0,62 \% \\
\text { Тупо } 0,62 \% \\
\text { Прикол } 0,62 \% \\
\text { Это связи, } \\
\text { опьтт, умение } \\
\text { вьбираться из } \\
\text { полной... } \\
\text { 0,62 \% }\end{array}$ & $\begin{array}{l}\text { Способ понять, } \\
\text { что курсы и } \\
\text { самообразование в } \\
\text { нынешней России } \\
\text { - лучшее средство } \\
\text { для достижения } \\
\text { любой иели 0,62 \% } \\
\text { Выполнение } \\
\text { требований } \\
\text { родителей 0,62 \% } \\
\text { Это связи, опьт } \\
\text { 0,62 \% } \\
\text { Цель, этап в } \\
\text { жсизни 0,62 \% } \\
\text { Выбор ленивых } \\
\text { 0,62 \% } \\
\text { Средство } 0,62 \%\end{array}$ & $\begin{array}{l}\text { Мама } \\
\text { заставила } \\
0,62 \% \\
\text { Желание пойти } \\
\text { работать } \\
\text { туда, куда } \\
\text { хочется, но не } \\
\text { всегда такое } \\
\text { возможно } 0,62\end{array}$ & $\begin{array}{l}\text { Случайность 0,62 \% } \\
\text { гапдот } 0,62 \% \\
\text { Не сдавал ЕГЭ } \\
5 \% \\
\text { То, что брат сдавал } \\
0,62 \% \\
\text { Выбор родителей } \\
0,62 \% \\
\text { Выббрал в состоянии } \\
\text { аффекта } 0,62 \% \\
\text { Было не } \\
\text { принципиально на } \\
\text { какую специильность } \\
\text { пойду, поэтому } \\
\text { вьбор предоставил } \\
\text { родителям } 0,62 \%\end{array}$ \\
\hline
\end{tabular}

Оказывается, более девяноста процентов информантов утверждают, что образование это хорошо или скорее хорошо, то есть ценность образования не утеряна. Однако, некоторые ответы (например, смотря какое, смотря где; плохо; скорее плохо; зачастую просто бесполезно и нудно; тупо, что составляет около $5 \%$ результатов) демонстрируют негативное отношения к системе образования, её структуре и стандартам. В обществе появляется отрицательное отношение ко всей образовательной системе в России. Соответственно, все больше людей стремится уехать заграницу и получить образование там. Современное образование нацелено, скорее, на формальное 
получение диплома о высшем образовании, а не на самосовершенствование человека, получение им новых знаний и умений. Знаменитые слова В.И. Ленина «Учиться, учиться и ещё раз учиться», к сожалению, не являются актуальными в современном обществе (хотя идеи, состоявшие в постижении науки и овладении ею, ценились и почитались во всем мире). Поэтому ответ «плохо», составляющий 2,4\% понятен и может рассматриваться как один из показателей качества системы образования в России. Ряд ответов показывают несерьезное отношение современных студентов к процессу получения образования (ответы прикол, Выбор ленивых).

При положительной динамике отношения к образованию, мнение о получении «вышки» (сленговое студенческое название высшего образования), содержит другие идеи и подразумевает иные цели. Студенты поддерживают процесс обучения, но не видят его в словосочетании «высшее образование», которому дают определения: связи, опьыт; способ понять, что курсы $u$ самообразование в нынешней России - лучшее средство для достижения любой иели; модно, престижно. То есть, по словам современных студентов, целью высшего образования для является скорее приобретение связей и престиж, чем необходимость получения знаний.

Будучи абитуриентами, не все студенты с пониманием подходили к выбору специальности. 10,6 \% поддались выбору судьбы, 11,8 \% было всё равно куда идти, просто было необходимо получить высшее образование, неважно какое, только для 45,3 \% это осознанный выбор и для 30,4\% их специальность то, что необходимо для достижения цели.

На следующем этапе исследования был проведен свободный ассоциативный эксперимент (далее САЭ), который широко используется как средство изучения психологического значения слова [2], категориального и предметного значения, особенностей развития слова у ребёнка, специфики значения некоторых слов, опорных слов сравнительных конструкций, связей между словами, организации лексикона человека [4]. Суть САЭ заключается в том, что испытуемому даётся слово-стимул и предлагается реагировать на это слово первым «пришедшим в голову» словом или словосочетанием [14].

С целью выявления образа университета, стоящего за относящимися к сфере образования словами образование, вуз, университет, в сознании современных студентов испытуемым было предложено дать ассоциации к словам. Результаты приведены в табл. 2-4 (полученные в ходе эксперимента ассоциации приводятся с сохранением орфографии и пунктуации испытуемых; С - слово-стимул, Р - слово-реакция).

Судя по полученным ассоциациям (см. табл. 2), отношение студентов к образованию серьёзно и значимо. Для 8 \% образование - это учёба, для 3,7 \% диплом, аналогичный показатель для ответа высшее, большой процент $(10,3)$ считают образование нуждой и необходимостью. Встречается также ответ нужно, но не знаю зачем. Здесь имеет место проблема понимания получения аттестата или диплома как чего-то «навязанно-нужного». 
Таблица 2. Результаты САЭ: реакции на стимул ОБРАЗОВАНИЕ

\begin{tabular}{|c|c|c|}
\hline $\mathrm{NgCC}$ & & $\mathrm{P}$ \\
\hline 1 & & 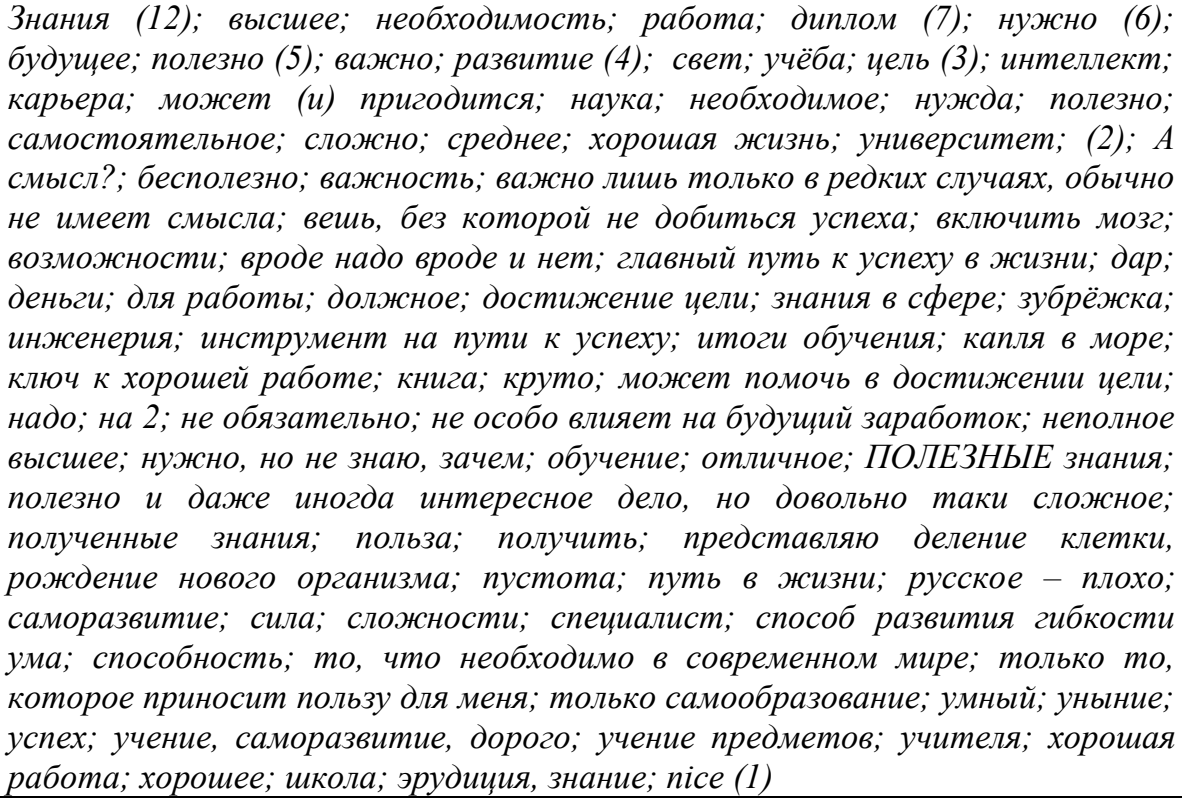 \\
\hline
\end{tabular}

Эта проблема получила свое отражение в ответах проведенного нами анкетирования относительно выбора будущей специальности и предметов для сдачи ЕГЭ (Мама заставила; Просто нужно высшее образование; Было не принциииально на какую специальность пойду, поэтому выбор предоставил родителям). Положительную оценку демонстрируют такие ассоциации, как сила, свет, эрудиция, полезно, интеллект, в противовес им - бесполезно, важно лишь только в редких случаях, обычно не имеет смысла, капля в море. Ассоциация русское - плохо хорошо соотносится с ответом полученным в ходе анкетирования Смотря какое, смотря где. Это еще раз подтверждает предположение о том, что ценность образования в современном обществе уменьшается.

Рассмотрим подробнее ассоциации к слову вуз (см. табл. 3). 27 человек связывают вуз с аббревиатурой названия своего университета - ЮЗГУ, 10 человек ассоциируют с учёбой, 10 - учебное заведение, по 6 - университет, образование, дом, по 3 -новые знакомства, перспективы, престиж, тогда как в русском ассоциативном словаре [7] престиж - наиболее часто встречающаяся реакция, что подтверждает динамичность значения слова в языковом сознании [11: 9]. Следовательно, студенты нашего университета показатель того, что престиж не является приоритетом их обучения, ВУЗ - это учебное заведение для получения образования, открывающее новые перспективы и знакомства. Единичными были варианты самостоятельность, свобода, Совокупность очевидной безосновательно усложненной информации, Создание связей для будущего, Долгий мучительныий путь, Внеплановое ухудшение здоровья. Последнее - одна из проблем, тревожащая многих студентов. Большое количество информации, другой уровень знаний по 
сравнению со школой, недостаток времени из-за самостоятельной жизни, переживания, недосып. Все эти факторы оказывают отрицательно влияние на здоровье, вследствие чего формируется, в какой-то степени, ложно-негативное отношению к университету.

Таблица 3. Результаты САЭ: реакции на стимул ВУЗ

\begin{tabular}{|c|c|c|}
\hline 2 & & 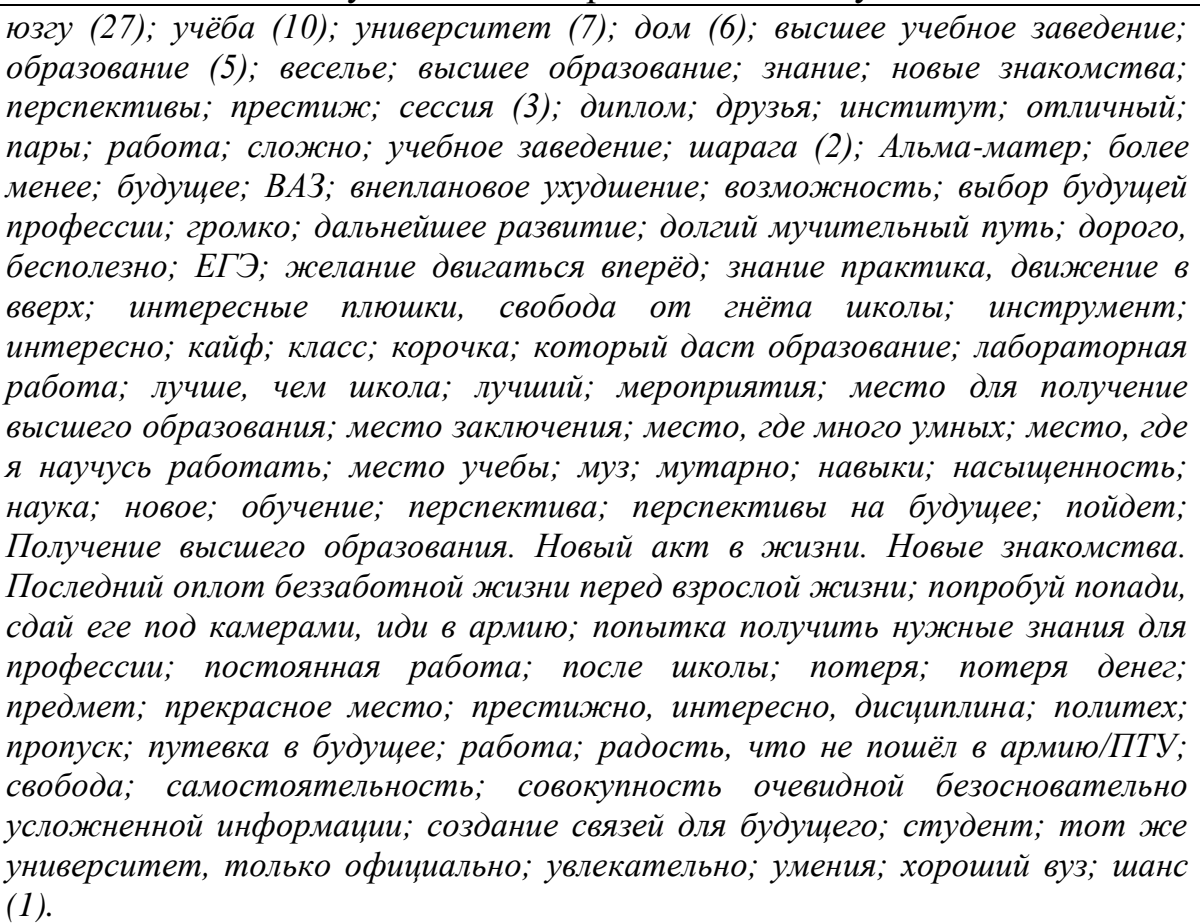 \\
\hline
\end{tabular}

Наиболее распространенные ассоциации к слову университет: высшее образование; образование (12); знания; учёба (9); обучение; пары (7); юзгу (6); будущее (5); шарага; престиж (4). В целом образ университета можно назвать неоднозначным. С одной стороны, это интересное место, в котором хочется находиться; место, где получаешь настоящие знания и друзей; любимое место. С другой стороны, «университет» как школа, только скучнее и нуднее; сказка о потерянном времени; трата времени; смерть; это дорого, тяжело, неактуально.

Далее было проведено исследование с использованием методики семантического дифференциала, достаточно широко используемой как в отечественной, так и в зарубежной психолингвистике $[5,6,10]$. Студентам было необходимо оценить по ряду шкал слова, использовавшиеся в первой части исследования. Метод семантического дифференциала был разработан в середине двадцатого века под руководством американского психолингвиста и психолога Ч. Осгуда, прежде всего для измерения значений слов. Значение, по Ч. Осгуду, - это «процесс или состояние поведения организма, использующего знак, которое рассматривается как необходимое следствие восприятия знаковых стимулов и необходимый предшественник производимых знаковых реакций» [15]. 
Таблица 4. Результаты САЭ: реакции на стимул УНИВЕРСИТЕТ

\begin{tabular}{|c|c|c|}
\hline 3 & & 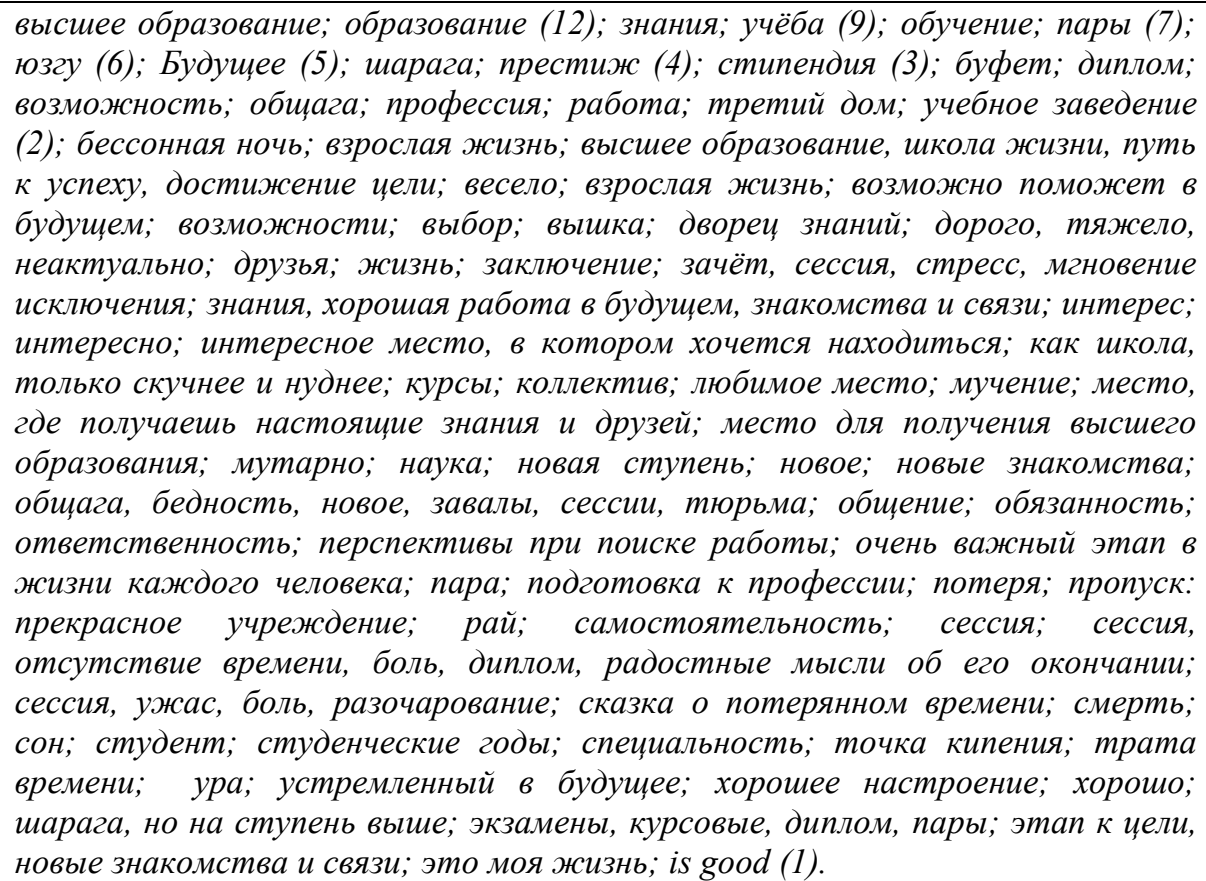 \\
\hline
\end{tabular}

Ч. Осгуд изучал «прагматические значения», опираясь при этом на известный факт, что в повседневной жизни человек постоянно сталкивается с тем, что стимул как некоторый знак и стимул как некоторый объект никогда не совпадают [1]. Он предположил, что реакция на знак «предположительно зависит от предшествующего ассоциирования знака с означаемым» [15].

Например, если человек воспринимает знак «опасность», то у него возникают такие же формы эмоциональных реакций, которые вызываются объектом, вызывающим реальную опасность [1]. Процедура проведения семантического дифференциала состоит в оценивании субъектом любых объектов по предлагаемым биполярным шкалам, заданных чаще всего прилагательными-антонимами [6].

В данной работе мы использовали неполную методику СД и проделали только первый этап, шкалирование. Для исследования использовались 18 биполярных шкал. Оценка варьировалась от -3 до +3 . В среднем, все результаты положительны. Общие результаты шкалирования представлены в табл. 5.

Таблица 5. Результаты исследования слова университет с помощью методики семантического дифференциала

\begin{tabular}{|l|c|c|c|c|c|c|c|}
\hline & -3 & -2 & -1 & 0 & 1 & 2 & 3 \\
\hline Неприятный - приятный & 4 & 1 & 3 & 18 & 19 & 45 & 71 \\
\hline Грустный - радостный & 4 & 0 & 3 & 19 & 26 & 59 & 50 \\
\hline Холодный - тёплый & 5 & 3 & 3 & 22 & 3 & 44 & 47 \\
\hline Пассивный - активный & 5 & 1 & 3 & 16 & 26 & 41 & 69 \\
\hline Серьёзный - смешной & 10 & 1 & 6 & 28 & 29 & 49 & 38 \\
\hline
\end{tabular}




\begin{tabular}{|l|c|c|c|c|c|c|c|}
\hline Статичный - динамичный & 5 & 6 & 7 & 16 & 25 & 53 & 49 \\
\hline Рациональный - эмоциональный & 7 & 5 & 7 & 20 & 25 & 47 & 50 \\
\hline Безобразный - прекрасный & 3 & 3 & 6 & 23 & 20 & 58 & 48 \\
\hline Неискренний - искренний & 9 & 1 & 8 & 24 & 30 & 46 & 43 \\
\hline Плохой - хороший & 2 & 2 & 3 & 21 & 22 & 46 & 65 \\
\hline Слабый - сильный & 3 & 2 & 2 & 23 & 22 & 55 & 54 \\
\hline Воинственный - миролюбивый & 11 & 12 & 12 & 25 & 25 & 42 & 34 \\
\hline Неформальный - формальный & 4 & 3 & 2 & 29 & 28 & 51 & 44 \\
\hline Возбуждающий - успокаивающий & 10 & 2 & 12 & 36 & 31 & 40 & 30 \\
\hline Отвергаемый - предпочитаемый & 4 & 4 & 3 & 24 & 21 & 47 & 58 \\
\hline Злой - добрый & 3 & 1 & 5 & 27 & 32 & 47 & 46 \\
\hline Негативный - позитивный & 5 & 1 & 5 & 19 & 19 & 53 & 59 \\
\hline Грустный - весёлый & 3 & 6 & 3 & 18 & 23 & 52 & 56 \\
\hline
\end{tabular}

Мы видим, что наиболее значимыми признаками формирования образа университета в сознании студентов являются «приятный», «активный», «хороший», «предпочитаемый», «позитивный».

Оценка по признаку «статичный-динамичный» (см. рис. 1) может являться показателем того, что вуз держит студентов в тонусе, в движении.

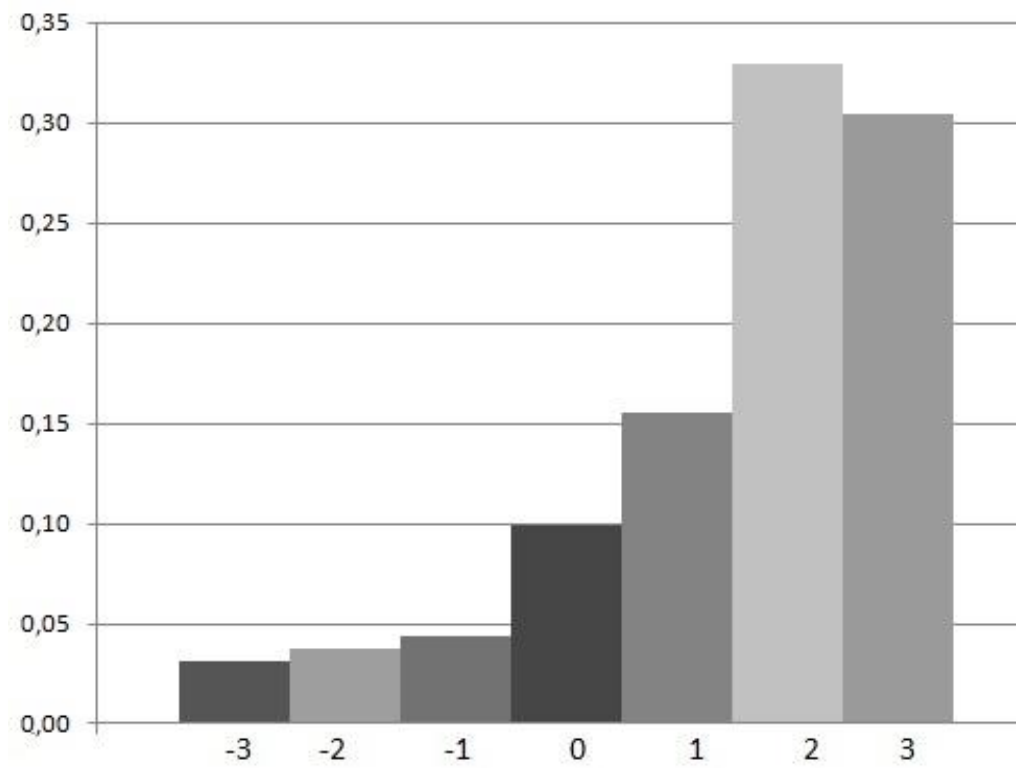

Рис. 1. Оценка по признаку «статичный-динамичный»

Из рис. 2 видно, что слово университет приятно обучающимся, нет сильного отторжения. 


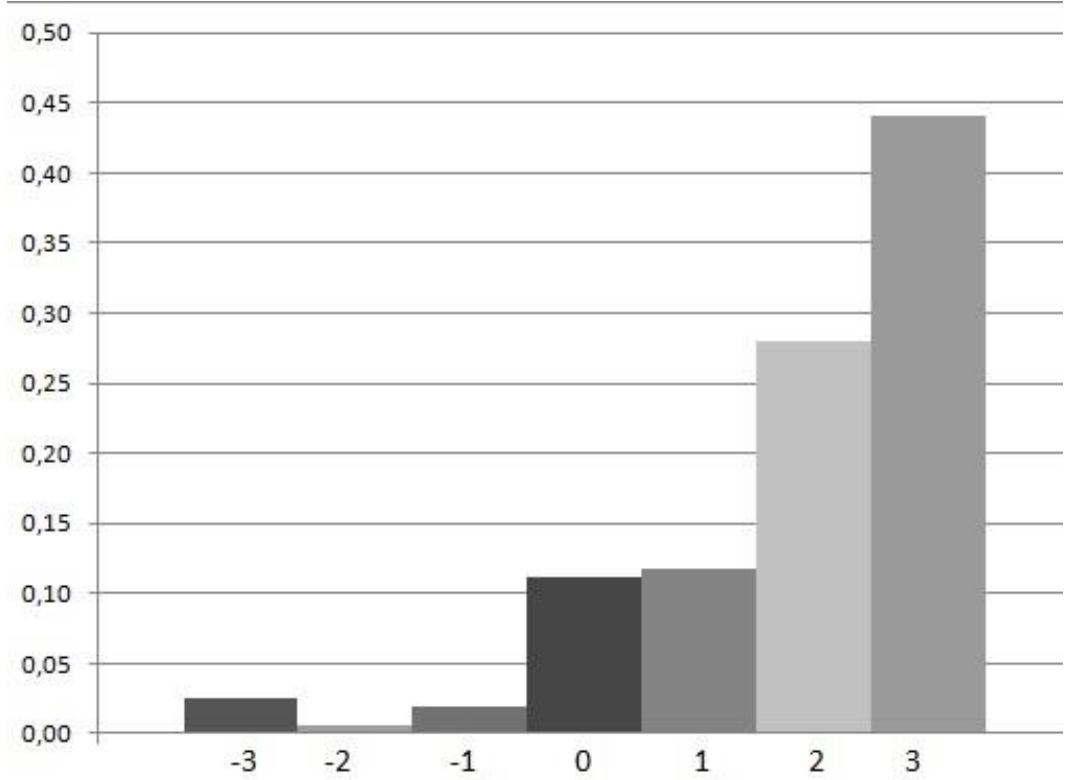

Рис. 2. Оценка по признаку «неприятный-приятный»

Из табл. 3 видно, что наивысшую оценку в отрицательную сторону имеет признак «воинственность» $(11+12+12)$, что составляет $21 \%$, то есть, около пятой части испытуемых отрицают миролюбивость учебного заведение, ощущают беспокойство и тревогу ( влияние различные факторы: переживание за учёбу, отношения с преподавателями, отношения с товарищами. Еще одной причиной выбора признака «воинственность» может служить открытие в нашем вузе военной кафедры.

Таким образом, путём использования экспериментальных методик мы исследовали образ университета, стоящий за словами образование, вуз и университет, в сознании современных студентов. По данным исследования образование для молодых людей, с одной стороны, имеет большое значение (нужно; будущее; полезно; важно; развитие; необходимость; вешь, без которой не добиться успеха; возможности; ПОЛЕЗНЫЕ знания; может помочь в достижении цели). С другой стороны, заметна несерьёзность при выборе абитуриентами будущей специальности; многие респонденты выражают свое недовольство университетом и системой высшего образования (университет - дорого, тяжело, неактуально; мутарно; трата времени; шарага, но на ступень выше). Многие современные студенты вообще не понимают, зачем нужно получение образования (A смысл?; важно лишь только в редких случаях, обычно не имеет смысла; нужно, но не знаю, зачем; вроде надо вроде и нет; бесполезно), для них это не обязательно, так как не особо влияет на будущий заработок. Думается, что результаты исследований подобного рода могут способствовать осознанияю необходимости модернизации существующей системы высшего образования (несмотря на то, что процент негативных оценок на данный момент невелик). В дальнейшем можно провести факторный анализ полученных в ходе шкалирования 
результатов с целью выявления факторов, оказывающих наиболее значительное влияние на формирование негативного отношения к университету в частности и к образованию в целом. Кроме того, представляется интересным выявление образа школы и среднего образования, стоящего за этими словами в сознании как студентов, так и представителей других возрастных и социальных групп.

\section{Список литературы}

1. Андреева Г.М., Богомолова Н.Н., Петровская Л.А. Зарубежная социальная психология XX столетия. М.: Аспект Пресс, 2001. 288 с.

2. Анненкова А.В. Особенности восприятия образной составляющей имиджевой рекламы (некоторые результаты ассоциативного эксперимента) // Известия ЮгоЗападного государственного университета. Серия: Лингвистика и педагогика. 2017. Т. 7. № 3 (24). С. 58-66.

3. Большая советская энциклопедия. URL: https://bse.slovaronline.com (дата обращения: 20.12.2019).

4. Залевская А.А. Вопросы психолингвистики. Калинин: Калининский гос. ун-т, 1982. 80c.

5. Зубкова О.С., Анненкова А. В. Специфика функционирования образов имиджевой рекламы в индивидуальном лексиконе: монография. Курск: Изд-во ЗАО «Университетская книга», 2017. 242 с.

6. Новиков А.Л. Метод семантического дифференциала: теоретические основы и практика применения в лингвистических исследованиях. Вестник РУДН, серия Теория языка. М.: РУДН, 2011. № 3. С. 6-71.

7. Русский ассоциативный словарь. В 2 т. Т.1. От стимула к реакции: Ок. 7000 стимулов / Ю.Н. Караулов, Г.А. Черкасова, Н.В. Уфимцева, Ю.А. Сорокин, Е.Ф. Тарасов. М.: ООО «Издательство Астрель»: ООО «Издательство АСТ», 2002.784 с.

8. Таныгина Е.А. Внутренний образ цветообозначения красный в сознании носителя русской культуры // Вопросы психолингвистики. М.: Институт языкознания РАН, 2011. № 1 (13). С. 166-173.

9. Таныгина Е.А. Внутренний образ цветообозначения фиолетовый в сознании носителя русской культуры // Вестник Тверского государственного университета. Сер. «Филология». 2011. № 4. Вып. 2 «Лингвистика и межкультурная коммуникация». Тверь: Твер. гос. ун-т, 2011. С. 218-226.

10. Таныгина Е.А. Исследование внутреннего образа слов-цветообозначений русского языка с использованием методики семантического дифференциала // «Вестник Вятского государственного гуманитарного университета». Филология и искусствоведение. Киров: ВятГГУ, 2011. № 1 (2). С. 35-41.

11. Таныгина Е.А. Образ цвета в сознании носителя языка: дис. канд. филол. наук. Курск: КГУ, 2012. С. 9.

12. Таныгина Е.А. Проблема соотношения знания и наименования (на примере цветообозначения черный) // «Ученые записки Орловского государственного университета». Серия «Гуманитарные и социальные науки». Орел: Орловский государственный университет, 2011. № 2 (40). С. 155.

13. Толковый словарь русского языка: В 4 т./ Под ред. Проф. Д. Ушакова. М.: ТЕРРАКнижный клуб, 2007. 752 с.

14. Cramer, Ph. Word Association. New York; London: Academic Press, 1968. 178 p.

15. Osgood Ch.E., Tannenbaum P.H. The Principle of Congruity in the Prediction of Attitude Change // Psychological Review. 1995. V.62. 


\title{
THE INNER IMAGE OF MODERN UNIVERSITY IN THE LANGUAGE CONSCIOUSNESS OF RUSSIAN STUDENTS
}

\author{
E.A. Tanygina, T.S. Nikitenkova
}

Southwest State University, Kursk

The article presents an experimental study of the modern university inner image in the language consciousness of Russian students. Association experiment and semantic differential are used in order to study the students' opinion about learning at university.

Keywords: university, image, association experiment, semantic differential

\section{Об авторах:}

ТАНЫГИНА Елена Александровна, кандидат филологических наук, доцент, доцент кафедры иностранных языков, Юго-Западный государственный университет, еmail: eabel@yandex.ru.

НИКИТЕНКОВА Татьяна Сергеевна, студентка факультета фундаментальной и прикладной информатики, Юго-Западный государственный университет, e-mail: eabel@yandex.ru. 